\title{
Information Communication Technology (ICT): The New Frontier of Child and Youth Care (CYC) Practice
}

\author{
Winston Bihis \\ BCYC, MacEwan University, Alberta, Canada \\ Emmalee Brosch \\ BCYC, MacEwan University, Alberta, Canada \\ Tehya Davey \\ BCYC, MacEwan University, Alberta, Canada \\ Mariah Hayward, \\ BCYC, MacEwan University, Alberta, Canada \\ Sinclair Larson \\ BCYC, MacEwan University, Alberta, Canada \\ Jannelle Quito, \\ BCYC, MacEwan University, Alberta, Canada \\ Gerard Bellefeuille \\ Professor \\ Department of Child and Youth Care MacEwan University \\ Alberta, Canada
}

\begin{abstract}
This exploratory course-based research investigates the use of information communication technologies (ICT) by child and youth care (CYC) students in their interactions with children, youth, and families. Data were collected through an online mixed closed- and open-ended survey. The data analysis consisted of a descriptive statistical analysis of the survey's closed-ended questions and a thematic analysis of the survey's open-ended questions. The findings revealed that CYC students are using ICT in their interactions with children, youth, and families and that the potential positive use of ICT should be addressed in a more significant way in the classroom.
\end{abstract}

Key words: child and youth care, course-based research, ICT, qualitative.

\section{INTRODUCTION}

There has been much concern about the use of information communication technology (ICT) by child and youth care practitioners in recent years. Despite the enormous role ICT plays in our daily lives and in the modern world, its use as a relational communication tool in child and youth care (CYC) education has been poorly explored. Moreover, CYC students are largely discouraged from using ICT in interactions with children, youth, and families. Yet, as a service-oriented discipline, it is important that CYC continuously progresses as a profession in order to remain 
Bihis, W., Brosch, E., Davey, T., Hayward, M., Larson, S., Quito, J. \& Bellefuille, G. (2020). Information Communication Technology (ICT): The New Frontier of Child and Youth Care (CYC) Practise. Advances in Social Sciences Research Journal, 7(3) 379-385.

relevant and responsive to the changing times. It cannot be denied that we live in a globalized world that is constantly influenced and shaped by sweeping technological and social change. With its roots in residential care, CYC education as a field of practice has been historically slow to embrace change in comparison to other helping professions (Bellefeuille \& Jamieson, 2008). As Bellefeuille and Jamieson explain:

Child and youth care, like any other type of dominant idea, can be understood as a paradigm embedded within its institutionalized frameworks of theoretical concepts and practices.... Our social institutions lead us to take for granted certain things as relevant, and certain things as good. It is important for the student of social affairs to challenge the conventional wisdom as to both relevance and goodness. Real understanding requires that one step back and take a careful look at the standards of right and wrong, of important and unimportant, that underpin the society in which one has grown up. Some will see the need for such change, some for little. What matters is that one exercise the responsibility to look critically. (p. 719)

The point is that with social change come new insights, with new insights come new theoretical perspectives, and with new theoretical perspectives come new practice methods. For example, in 2004 Garfat wrote:

There was a time in our professional history when the family was not seen in a positive light. Indeed, in the early days of our field, family was considered irrelevant (Fewster \& Garfat, 1993). Then when it did become relevant, it was considered negatively so... (p. 4)

More recently, in commenting on some of the traditional behavioral management practices previously used in residential care, Gharabaghi (2010) offers the following confession:

Over the course of my career, I have always had a paradoxical disposition toward group homes. On the one hand, I loved working in them and I believed firmly that it is in fact possible to provide for meaningful experiences for young people within the context of residential group care. On the other hand, except for very short periods of time, my experiences of working in group homes have consistently confirmed that this is no way to care for kids. More than once I came to the conclusion that residential group care is really a nuanced way of practicing institutional child abuse. (para. 1)

The reality is that the incredible growth in ICT (e.g., smartphones, tablets, online forums, social media networks, texting, face-time videoing) over the past two to three decades has reshaped how every helping profession interacts with clients, and the field of child and youth care (CYC) is no exception (Barak \& Grohol, 2001; Finn, 2006). The field of CYC began when telephones were attached to walls by cords, progress notes were produced on typewriters, professional journals and books appeared only in hard copy, and services were provided to clients exclusively in physical offices or homes. Fast-forward, and CYC students entering the field today have the option to communicate with children, youth, and families on social networking sites, engage in online video conversations, and exchange email and text messages with clients by using smart devices. Without question, the rise and prevalence of ICT has altered how CYC education must 
think about how CYC practitioners will and are communicating with children, youth, and families in today's online world. A review of the literature shows that other helping professions are using ICT to communicate with clients and as a means of assessing and tracking needs, providing online support, and engaging in intervention strategies (Alleman, 2002; Boydell \& Pignatiello, 2020; Brezinka, 2008; Calear, Christensen, Mackinnon, Griffiths, \& O'kearney, 2009; Cunningham, \& Wuthrich, 2008; Gowen, Deschaine, Gruttadara, \& Markey, 2012: Roy \& Gillett, 2008). The purpose of this course-based research is to explore how CYC students are currently using ICT in their interactions with children, youth, and families.

\section{UNDERGRADUATE COURSE-BASED RESEARCH: A PEDAGOGICAL TOOL USED TO FOSTER CRITICALITY, REFLECTIVITY, AND PRAXIS}

The Bachelor of Child and Youth Care program at MacEwan University is continuously searching for new pedagogical approaches to foster criticality, reflectivity, and praxis, all of which the program considers integral components of the overall student educational experience. As such, the design and implementation of a course-based approach, in contrast with the traditional didactic approach to research-methods instruction, offers fourth-year undergraduate students the opportunity to master introductory research skills by conceptualizing, designing, administering, and showcasing small, minimum-risk research projects under the guidance and supervision of the course instructor (commonly, a professor with an extensive background in research and teaching).

The use of course-based research in higher education has increased substantially in recent years (Allyn, 2013; Bellefeuille, Ekdahl, Kent, \& Kluczny, 2014; Harrison, Dunbar, Ratmansky, Boyd, \& Lopatto, 2010). The benefits derived from a course-based approach to teaching research methods for CYC students are significant. First, there is value in providing students with authentic learning experiences that enhance the transfer of knowledge learned in traditional education practice. For example, former students have reported that their engagement in course-based research enabled them to deepen their scientific knowledge by adopting new methods of creative inquiry. Second, course-based research offers students the opportunity to work with instructors in a mentoring relationship; one result is that a greater number of student's express interest in advancing to graduate studies. Third, results generated through course-based research can sometimes be published in peer-reviewed journals and online openaccess portals and thereby contribute to the discipline's knowledge base.

The ethical approval required to permit students to conduct course-based research projects is granted to the course instructor by the university's research ethics board (REB). Student research groups are then required to complete an REB application form for each course-based research project undertaken in the class; each application is then reviewed by the course instructor and a sub-REB committee to ensure each course-based research project is completed and is in compliance with the ethics review requirements of the university.

\section{RESEARCH DESIGN}

The research design for this course-based study was informed by the interpretivist paradigm that posits that the world is socially constructed and reality is a subjective experience (Creswell, 2013). As Yin (2013) explains, while no research paradigm is objectively superior, the choice of paradigm should be congruent with the way a researcher understands the nature of reality. The 
Bihis, W., Brosch, E., Davey, T., Hayward, M., Larson, S., Quito, J. \& Bellefuille, G. (2020). Information Communication Technology (ICT): The New Frontier of Child and Youth Care (CYC) Practise. Advances in Social Sciences Research Journal, 7(3) 379-385.

interpretivist paradigm is closely associated with qualitative studies that seek to capture the subjective meaning of participants' experiences and acknowledges the self-reflective nature of researchers as interpreters of data (Creswell, 2013). As such, our inquiry was conducted as a basic qualitative study. This approach was chosen to enable participants to express themselves openly and without constraint.

\section{RESEARCH QUESTION}

The objective of this course-based research is to investigate the following research question: How do CYC students use technology in their relationships with children, youth, and families?

\section{Sampling Strategy}

A non-probability, purposive sampling strategy was used to recruit participants for this coursebased study. Participants were second-, third-, and fourth-year CYC students at MacEwan University. According to Creswell (2013), the most important factor in choosing study participants is ensuring that they fit with the research questions. The target sample population in our study included 10 participants from each year of study. The actual sample was three (3) second-year students, seven (7) third-year students, and seven (7) fourth-year students.

\section{Data Collection Strategy}

An online survey transmitted by email was used to collect data. Invitation to complete a survey by email have become a common data collection strategy (Bosnjak, Neubarth, Couper, Bandilla, \& Kaczmirek, 2008; McCoyd \& Kerson 2006). According to Hunter, Corcoran, Leeder, and Phelps (2013) and Sappleton (2013), the use of email as a data collection method allows researchers to obtain results quickly and at minimal cost. As a means of data collection, the email survey offers an increased sample size, greater sample diversity, easier access and convenience, lower costs and time investment, and many other appealing features as compared to other methods (Corley \& Jansen, 2000).

\section{Data analysis}

The data analysis consisted of a descriptive statistical analysis of the survey's close-ended questions and a thematic analysis of the survey's open-ended questions.

\section{Descriptive Statistical Analysis}

The sample consisted of 3 second-year students, 7 third-year students, and 7 fourth-year students. Among the participants, 11 worked in residential care, 3 worked in schools, 1 worked in children's services, another 1 worked at a drop-in center, and 1 did family work. Table 1 provides a summary of the close-ended survey responses. It is notable that $67 \%$ of participants who used ICT to communicate with youth worked in residential care. The likely explanation is that there is more flexibility when it comes to communication with youth in residential settings as compared to school settings. 
Table 1. Closed-ended survey responses. Close-Ended Survey Responses

$29 \%$ of participants work with youth aged $0-11$ years

$71 \%$ of participants work with youth aged $12-24$ years

$82 \%$ of participants communicated with youth online while on shift

$6 \%$ of participants communicated with youth online while off shift

$12 \%$ communicate both on- and off-shift

$12 \%$ of participants said they would respond if a youth messaged them outside of work hours

$47 \%$ of participants said they would NOT respond if a youth messaged them outside of work hours

$41 \%$ of participants said it would depend on the circumstances, such as whether the youth was in crisis

$67 \%$ of participants who communicated online worked in a residential setting

Online platforms used to communicate with youth included email, Facebook, texting, Instagram, and Snapchat.

\section{Thematic Analysis}

Braun and Clarke's six-stage thematic analysis process was used to extract themes from the open-ended questions. Three themes were identified supporting why participants prefer to use ICT to communicate with youth in their roles as CYC practitioners.

\section{Text messaging}

The most-used ICT platform for communicating with youth was text messaging, followed by Facebook. This finding was not surprising considering that text and Facebook messaging are affordable, widely accessible, and relevant to youth populations. Many youth are "digital natives" and have never known a world without the internet. It is possible that many youths therefore expect that their CYC worker will communicate using technology such as email, text messaging, Skype, Facebook, or other social media.

\section{Checking-in as a form of support}

One of the main reason's participants provided for using ICT to communicate with youth was for the ease of checking-in with youth or offering support and positive encouragements. These participants noted that ICT is an extension of the life space and therefore viewed as a practical way to engage with youth in care. Participants also suggested that ICT can bring psychological and emotional benefits to youth in care, outweighing the potential risks it poses (e.g., confidentiality, boundary crossing).

\section{Supervision}

The other main reason noted by participants for use of ICT was to monitor youths' activities when left unsupervised, as well as a means to monitor their safety. For example, one participant noted, "I would always respond to youth if they were in trouble or need to vent/disclose about a situation". Another participant stated, "I would as it could be an emergency and I think it is the most modern way to connect with youth". These participants used ICT with youth in an effort to 
Bihis, W., Brosch, E., Davey, T., Hayward, M., Larson, S., Quito, J. \& Bellefuille, G. (2020). Information Communication Technology (ICT): The New Frontier of Child and Youth Care (CYC) Practise. Advances in Social Sciences Research Journal, 7(3) 379-385.

be more client-centered and responsive, and because they find this mode of communication to be more suitable in today's world.

\section{DISCUSSION}

It cannot be ignored that today's youth use ICT regularly. In fact, the current generation of young people have lived a digital existence for their entire lives. Stats Canada (2018), for example, reported that almost all Canadian youth between the age of 15 and 24 access ICT on a regular basis. In a recent course-based study conducted by Arago et al. (2019), it was reported that ICT:

Has become a vital aspect of the lives of children and youth. Connecting with youth through these platforms can, therefore, be a useful tool for building relationships and engaging in therapeutic work for CYC practitioners. As young adults who have entered the field of CYC, we are both confident and adept in the use of information and communication technologies. So why not embrace what social media has to offer, while keeping in mind the professional boundaries and ethical challenges that these sites present for CYC practitioners. The reality is social media and other online technologies have already fundamentally transformed the way in which CYC practitioners and youth interact with each other. (p. 13)

There is a growing body of evidence that demonstrates the potential of ICT for interventions to reduce risk behavior and provide support to youth (Burleson \& Kaminer, 2007; Devine, Bull, Dreisbach, \& Shlay, 2014; Kiene \& Barta, 2006; Rice, Lee, \& Taitt, 2011). Whether we like it or not, ICT is an integral and essential feature of modern life. To this end, CYC educators must critically reflect on how we move forward as a relational-centered field of practice that includes the use of ICT. Though ICT does receive some attention in CYC literature and in the classroom, we do not believe that it is adequate, and it is mostly focused on the perils of using ICT. We need to move beyond focusing on the security and privacy concerns that surround the use of ICT and instead focus on its potential positive use by CYC practitioners. Of course, this requires CYC instructors who are comfortable exploring the positive use of ICT as a means to provide ethically driven, therapeutic intervention. It is without question an issue that the field must begin address.

\section{References}

Alleman, J. R. (2002). Online counselling: The internet and mental health treatment. Psychotherapy, 39, 199-209.

Allyn, D. A. (2013). Course-based undergraduate research: It can be accomplished! Journal of Physical Education, Recreation \& Dance, 84(9), 32-36.

Arago, T., Ali, S., Dassouki, T., Massner, S., Mendiola, D., Po, J., Sun, K., \& Bellefeuille, G. (2019). Social media and 21st century child and youth care practice. Journal of Education, Teaching and Social Studies, 1(1), 12-20.

Barak, A., \& Grohol, J. M. (2011). Current and future trends in Internet-supported mental health interventions. Journal of Technology in Human Services, 29, 155-196.

Bellefeuille, G., Ekdahl, C., Kent, L., \& Kluczny, M. (2014). A course-based creative inquiry approach to teaching introductory research methods in Child and Youth Care undergraduate education. International Journal of Teaching and Education, 2(2), 1-9.

Bellefeuille, G., \& Jamieson, D. (2008). A Pedagogical Response to a Changing World: Towards a Globally-Informed Pedagogy for Child \& Youth Care Education and Practice. Children and Youth Services Review, 30, 717-726. 
Bosnjak, M., Neubarth, W., Couper, M. P., Bandilla, W., \& Kaczmirek, L. (2008). Prenotification in web-based access panel surveys: The influence of mobile text messaging versus e-mail on response rates and sample composition. Social Science Computer Review, 26, 213-223.

Boydell, K. M., Volpe, T., \& Pignatiello, A. (2010). A qualitative a study of young people's perspectives on receiving psychiatric services via televideo. Journal of the Canadian Academy of Child \& Adolescent Psychiatry, 19(1), 5-11.

Brezinka, V. (2008). Treasure hunt: A serious game to support psychotherapeutic treatment of children. Studies in Health Technology and Informatics,136, 71-7.

Burleson, J.A., \& Kaminer Y. (2007). Aftercare for adolescent alcohol use disorder: Feasibility and acceptability of a phone intervention. The American Journal on Addictions, 16, 202-205.

Calear, A. L., Christensen, H., Mackinnon, A., Griffiths, K. M., \& O'kearney, R. (2009). The YouthMood Project: A cluster randomized controlled trial of an online cognitive behavioral program with adolescents. Journal of Consulting and Clinical Psychology, 77(6), 1021 -1032.

Corley, K.G., \& Jansen, K.J. (2000). Electronic survey techniques: Issues and implications. Paper presented at the academy of management annual meeting, Toronto, Canada. Retrieved from https://www.researchgate.net/publication/267836472_E-Survey_Methodology

Creswell, J. W. (2013). Qualitative inquiry and research design: Choosing among five approaches (3rd ed.) CA: Sage: Thousand Oaks.

Cunningham, M., \& Wuthrich, V. (2008). Examination of barriers to treatment and user preferences with computerbased therapy using the Cool Teens CD for adolescent anxiety. E-Journal of Applied Psychology, 4(2), 12 -17.

Devine, S., Bull, S., Dreisbach, S., \& ShlayJ.(2014) Enhancing a teen pregnancy prevention program with text messaging: engaging minority youth to develop Top® Plus Text. Journal of Adolescent Health, 54(3), 78-83.

Finn, J. (2006). An exploratory study of email use by direct service social workers. Journal of Technology in Human Services, 24, 1-20.

Garfat, T. (2004). A child and youth care approach to working with families. New York: Haworth Press

Gharabaghi, K. (2010). Three profoundly stupid ideas. CYC-Online. Retrieved from http://www.cyc-net.org/cyconline/cyconline-aug2010-gharabaghi.html

Gowen, K., Deschaine, M., Gruttadara, D., \& Markey, D. (2012). Young adults with mental health conditions and social networking websites: Seeking tools to build community. Psychiatric Rehabilitation Journal, 35(3), 245-250

Harrison, M., Dunbar, D., Ratmansky, L., Boyd, K., \& Lopatto, D. (2010). Classroom-based science research at the introductory level: Changes in career choices and attitude. CBE Life Sciences Education, 10(3): 279-86.

Hunter, J., Corcoran, K., Leeder, S., \& Phelps, K. (2013). Is it time to abandon paper? The use of emails and the Internet for health services research-A cost-effectiveness and qualitative study. Journal of Evaluation in Clinical Practice, $19,855-861$.

Kiene, S.M., \& Barta, W.D. (2006). A brief individualized computer-delivered sexual risk reduction intervention Increases HIV/AIDS Preventive Behavior. Journal of Adolescent Health, 39(3), 404-410.

McCoyd, J. L. M., \& Kerson, T. S. (2006). Conducting intensive interviews using email: A serendipitous comparative opportunity. Qualitative Social Work, 5, 389-406.

Rice, E., Lee, A., \& Taitt, S. (2011). Cell phone use among homeless youth: potential for new health interventions and research. Journal of Urban Health, 88, 1175-1182.

Roy, H., \& Gillett, T. (2008). Email: A new technique for forming a therapeutic alliance with high-risk young people failing to engage with mental health services? A case study. Clinical Child Psychology and Psychiatry, 13, 95-103.

Sappleton, N. (2013). Advancing research methods with new technologies. Hershey, PA: IGI Global.

Yin, R. K. (2013). Case study research: Design and methods (5th ed.). Sage Publications, Los Angeles. 